\title{
Netizens' Comments in Responding Polling of Presidential-VP Candidate 2019 on YouTube: Rocky Gerung's Channel
}

\author{
Nico Harared ${ }^{1}$, Irfan Hadi ${ }^{2}$ \\ nico.hrd@gmail.com ${ }^{1}$, pakirfan@ rocketmail.com ${ }^{2}$ \\ Universitas Indraprasta PGRI ${ }^{1,2}$
}

\begin{abstract}
The aim of this research is to describe the expressive speech acts of the YouTube user (netizen) and the politeness strategy used by the netizens in line to respond polling of Presidential-VP candidate in Indonesia. This descriptive qualitative research used library research in collecting the data. Some theories related to expressive speech acts and politeness strategy were used to analyze the data. The analysis was represented by using informal method. The result of analysis showed that the expressive speech act is the most frequently used by the YouTube users. The results indicated that the netizens used expressive speech acts to express anger, satirizing, sympathizing, blaming, thanking and fulminating. The research also revealed the importance of expressive speech act in keeping politeness in witten language. It was concluded that the netizens were creative in expressing their ideas through written language. Expressive speech acts and politeness strategy reflected the way the language users show their emotion by using words.
\end{abstract}

Keywords: expressive speech acts, netizens' comments, politeness strategy, Rocky Gerung

\section{Introduction}

For many young people, YouTube is used to watch music videos, comedy shows, how to guides, recipes, hacks and more. Teens also use the video-sharing service to follow their favorite vloggers (video blogger), subscribe to other YouTubers and celebrities they are interested in. We know already that YouTube can be a very popular platform, as they add a dynamic element to your video, improve knowledge transfer, demonstrate procedures, and to share some topics. This is why the video sharing website YouTube can provide unlimited opportunities to enhance our mind by not only using countless videos you can find there, but also creating our own survey to help our audience achieve their objectives.

People commonly use YouTube in order to see some video informative, funny, awesome and even inspiring. Started from civil society, teenagers, public figures, artists even politicians. YouTube not only as a platform to upload and watch videos, but also there is a new feature in YouTube. As mentioned before, there's a feature in YouTube to create own survey. One of the rising politician and also YouTuber is Rocky Gerung. Rocky Gerung is a lecturer of philosophy at the prestigious Universitas Indonesia (UI). He becomes so popular since his appearance on tvOne's popular debate show Indonesia Lawyers Club (ILC) by saying holy books are fiction on Tuesday, April 10, 2018 (The Jakarta Post, 2018). His followers on twitter were increasing significantly and his subscriber on YouTube as well.

On August 9, 2018, President Joko Widodo and Gerindra's Chairman Prabowo Subinto's announced their choice of running mates in the 2019 presidential election dramatically then changed the dynamics of the race from almost anything analysts had previously predicted. Now, the results first survey of potential voters polled after the running mate announcements were made have been showed, and they indicate that while 
the incumbent still holds a major advantage over Prabowo in previous polls, demographic shifts among their voters could herald major shifts in campaign strategies.

Based on the phenomena, Rocky Gerung also created and released his own survey at his own YouTube channel. He did a survey for his follower (netizen) to participate in his account to choose the President and VP candidate of Indonesia in 2019. The results of a voter survey held from August 12-30, 2018. Based on a head-to-head match, $8 \%$ of voters would pick President Jokowi and his running mate, Indonesian Ulema Council (MUI) leader Ma'ruf Amin, while 92\% would pick Prabowo and his running mate, former Jakarta vice governor and businessman Sandiaga Uno (Gerung, 2018). Netizen's reaction is literary interesting to be analyzed. The aims of this research to describe expressive speech act and to describe the politeness strategy netizens' in responding polling of PresidentialVP candidates on YouTube: Rocky Gerung's channel.

Some researchers have conducted speech acts and politeness analysis in some particular researches. These researchers analyzed and investigated speech acts and politeness analysis in such discussions, such as Septianasari (2018) investigated a study about netizen's comment in responding to social phenomenon e-KTP corruption on Instagram. The result showed that the netizen used expressive speech act for cursing, expressing anger, satirizing, sympathizing, blaming, thanking, fulminating, and advising. Most of them used this speech act to express their anger or negative emotion. Then, Budiarta et al (2018) discussed about politeness and violations in the Adit dan Sopo Jarwo program. The result of the analysis shows that there are three types of politeness maxim exemplified in the animation; tact, approbation, and generosity. Politeness violations occur with the tact, agreement, and generosity maxims. The utterances that show politeness are uttered by the characters Jarwis, Ujang, Denis, and Mr. Habibie whereas the utterances that show politeness violations are uttered by Ujang, Denis, Devi, and Jarwo. Aarons and Mierowsky (2017) conducted some of the speech acts used in the work of selected standup comedians to analyse the way they determine the relationship of performer and audience. They argued that there is a reciprocal relationship between the licensing of certain speech acts in standup comedy, and the success of these speech acts in shaping the social lives of the audience. They showed that this relationship is at the forefront of standup comedy's social impact and that it can generate heightened consciousness of the social and political environment of the time. Finally, they considered the question of whether socially critical standup can have any noticeable effect on the attitudes or behaviour of both live and digitally mediated audiences. Iriyansah (2017) conducted the realization of a directive speech act category in the movie entitled "Negeri Lima Menara". The results shown in the movie "Negeri Lima Menara" are six categories of speech acts directive. Directive politeness asking category frequently used by speakers in a conversation to express her wishes. Revita et al (2017) investigated the politeness strategy used by panders in persuading women to be the victim of women trafficking. The research is conducted in West Java (Bekasi, Cirebon, and Indramayu). Having analyzed data, it is found that there are four politeness strategies used by the panders in woman trafficking activities. They are (a) bald on record; (b) positive politeness; (c) negative politeness; and (d) off record. The politeness strategies used by the members of a Betawinese family in their daily conversation conducted by (Salihah \& Winiharti, 2017). The result showed that there are four politeness strategies used: Bald on record, off record, Positive politeness and Negative politeness. This study has also found that the selection of politeness strategies is determined by two factors; (a) the status of the family members within the family itself and (b) the intensity of inter-speaker meeting. Generally, it is proven that Betawinese families apply politeness strategies in their daily conversation. Keywords: Politeness strategy, 
family member, family status, conversation. Widya (2017) tried to describe types of speech acts performed by English lecturers in learning process at STKIP YDB Lubuk Alung. The research findings show that there were four types of speech acts performed by the English lecturers, namely representatives, directives, expressive and commissives, whereas declarations were not utilized by the English lecturer. The most frequently used illocutionary acts were directives $(53 \%)$, while the least frequent illocutionary acts went to commissives $(5 \%)$. The frequent use of directives indicates that the lecturer seemed to be aware of their status as a lecturer which was believed to be more powerful than her students.

The form, function and response strategies from autistic students on the teachers' directive in the classroom done by Robiah and Ibrahim (2016). This study used a case study. The results showed that there are two categories of the students' spoken responses: (1) speech production in the form of assertive, directive, commissive and expressive; and (2) the speech responses are based on the senses including auditory, visual and emotions. In addition, the function of the students' responses is categorized into two: (i) the effect of speech production in terms of complaining, agreeing, asking, stating something, thanking, apologizing, asserting, reporting, mentioning and offering; and (ii) the students' responses as the effect of the teachers' directive speech acts. Furthermore, the students' response strategies are divided into two categories, namely: (i) internal and external factors, and (ii) the delivery of the students' responses. (Gillani \& Mahmood, 2014) also explored the politeness strategies used in Pakistani business letters written in English. This study is very insightful for teachers and learners regarding the usage of politeness strategies in business communication. The textbook writers can benefit from this research as it will acquaint them with the differences in the use of politeness strategies for intra-national and international business communication. (Syafruddin \& Rimang, 2014) investigated and explained declarative, interrogative, and imperative forms as well as speech act strategies used by the members the South Sulawesi Parliament. The findings revealed that there were various forms of politeness used by the respondents. Moreover, the locution act was the more dominant strategy used by the respondent than the illocutionary act. (Muhartoyo \& Kristani, 2013) conducted speech acts in case directive speech act. Their study aims to identify the directive speech act in "Sleeping Beauty" movie. The result of analysis showed that the directive speech act of ordering is the most frequently used in the movie $(21,6 \%)$. The least frequently used directive speech act is inviting directive speech act $(0,7 \%)$. The study also revealed the importance of directive speech act in keeping the flow of storyline of the movie. (Suwignyo, 2011) also described and found the laku among utterance in the class discourse. Laku Among speech act is a natural phenomenon of language use in social and cultural among contexts. To explain the phenomena, ethnographic research was used based on the structure of classroom communication. The result of the study shows that there are three findings of using laku among utterances in the classroom, they are ing ngarsa, ing madya, tut wuri handayani in the initial, middle and final speech acts in the classroom discourse.

Since speech act has been extensively studied, however, less attention paid to language phenomena in case of speech act from YouTube users reaction especially for 2019 in political year in Indonesia.

\section{Method}

The research employed a qualitative approach by using the YouTube channel as the source of data. Library research was used to collect the data. The writers collected primary data that were derived from several comments on YouTube: Rocky Gerung's channel. Once the data were collected, they were then classified into categories seen from its speech 
acts and its politeness. The data were translated by the researchers themselves. Some theories about speech acts introduced by Searle (1979), Yule (2006), and Brown and Levinson (1983) were used to analyzed the data.

\section{Findings and Discussion}

Generally, there are 5 types of speech act found in netizen' comments. Searle (1979) and Yule (2006) pointed out that those speech acts are declarative, representative, expressive, commissive, and directive. This research will be focused on the expressive speech act and politeness strategy of netizen's comment in responding Rocky Gerung's polling.

\section{Expressive Speech Act of Netizen's Comment}

Expressive speech act shows psychological utterances of the speakers. They use this speech act for thanking, congratulating, criticizing, complaining, and more. Expressive illocution tends to be uttered pleasurably. Therefore, this illocution is intrinsically polite, except expressive illocution for threatening or accusing (Hikmah, 2013).

The source of data is every comment on YouTube: Rocky Gerung's channel consists of expressive speech acts and politeness. The data show that most of the YouTube users gave some expressions in their comments. Here are the types of expressive speech act of netizen's comments in responding Rocky Gerung's polling:

\section{a. Expressing Anger}

Some people use utterance to show their anger. The speakers commonly use swears words when they are angry. Here are the data of the expressive illocution that show the anger of YouTube users.

(1) @ cahaya langit malam: KAMBING KURUS diseruduk NENE BANTENG dikelilingi SRIGALA LAPAR sama CEBONG DUNGU. Ga mau ah pemimpinnya yg kaya gitu (Translation: THIN GOAT was hit by MOTHER OF BULL and was sorrounded by HUNGRY WOLF with STUPID TADPOLE, I don't wanna have such a leader like that).

(2)@azzura official:

Tenggelamkan Cebong (Translation: drown tadpole).

The datum (1), the netizen used swears word to express his anger. On the other hand, the utterance shows that the netizen used swear word by represent animal figure to emphasis his anger. Meanwhile in the datum (2) shows that the netizen used imperative sentence to reflect his anger toward the survey. The word tenggelamkan is popular sentence from Susi Pudjiastuti, minister of marine.

\section{b. Satirizing}

The netizen user used satire in responding the Rocky Gerung's Survey. They expressed their comments emotionally by using this language style. Look at the data below!

(3) @zein alby:

Saya memilih Jokowi dan Maruf Amin untuk beristirahat di 2019. Cukup sudah angeran yang selama 5 tahun berkuasa, cukup sudah bertanya kepada sang ibu.... dan satu lagi biarkan di 2019 pangeran ini belajar di depan umum tanpa teks....... (Translation: I choose Jokowi and Maruf Amin to take a rest in 2019. Enough for the lovely prince hold the power in 5 years. Enough for asking to his 
beloved Mother.... and let the lovely prince learn how to communicate in public speaking without text....).

Here, @zein alby was not praising Mr President as a real prince through his comments which is shown in datum (3). He assumed that the lovely Prince was learning public speaking without text. In fact we know that a prince is the best person in handling everything.

\section{c. Sympathizing}

According to Rocky Gerung's channel, some netizens sympathized for phenomenon occurred in this pooling. Here are some data that show how YouTube users express their sympathy.

(4) @Fandrei Larch Leonard: sebetulnya saya kurng setuju mengenai keputusan pak jokowi memilih kiyai maruf amin sebagai wakilnya.... jujur belakangan saya menaruh simpati kepada pak prabowo entah kenapa, dengan sejenak mengesampingkan rekam jejak beliau. Saya lebih setuju keduanya dipasangkan (JOKOWI-PRABOWO) (Translation: actually, when Jokowi choose Ma'ruf Amin as VP candidate, I doubt with that... Honestly, I don't know why, lately I put my sympathy to Mr. Prabowo by putting aside his previous track record in Human right problem. My expectation is Jokowi and Prabowo for President and VP. Some citizens express their disappointment and anger by uttering any words. However, the other citizen gives different reaction toward this phenomenon. Some of them express their sympathy through the comments they write on YouTube comment. It can be seen from datum (4). Netizen in datum (4) blame Mr. President after choose his mate in the following president election, but on the other hand, he gives his sympathy for Mr. Prabowo and hope Jokowi and Prabowo become a mate in 2019).

\section{d. Blaming}

Some data bring out several comments which had been uttered to blame the president. Look at the data below!

(5) @ Fitransyah delly: Habisnya jokowow cuma bisa pencitraan doang tapi janji2 PILPRES hn 2014 ga ada yang ditepati..selain itu katanya ulama ga boleh berpolitik, kenyataannya malah ambil calon wapres dr ulama. Lain dimulut lain dihati. Di agama disebut $M^{*} N @ F^{*} K$. (Translation: Jokowow cannot implement his promises in PILPLRES 2014. Meanwhile, previously, his statement forbids Ulema in politic, in fact he chooses ulema as his VP candidate. In Islam, this case is called munafik).

In datum (5), the netizen blamed Mr President because he can not implement his promises and his VP candidate from ulema.

\section{e. Thanking}

Some people also express their thanks and gratitude in comment. It is proven in the datum (6) and (7) below.

(6)@novrie:

TKS mas Rocky atas polling survey nya (Translation: Thank you Mr Rocky for your polling [survey]). 
(7)@Gugun Kruger:

saya bersyukur wakil pak jokowi adalah kiyai maaruf amin, pak amin lebih baik istiqomah di jalan allah, sudah terlalu tua kiyai untuk memimpin negeri. Semakin mantap untuk memilih pak Prabowo dan Sandi. (Translation: my gratitude for VP candidate is Kiyai Ma'ruf Amin, Mr. Amin better stay on the track as ulema, (Amin) too old to lead this country. My confidence increases to choose Prabowo and Sandi).

It seems like these netizens wanted to point out their gratitude for this polling and survey. It indicates by the word thanks and gratitude.

\section{f. Fulminating}

Another expression that people showed in responding to President and VP candidate in Rocky Gerung's Channel is fulminating. This expression is found on netizen's comment as well. Here is the datum that shows the expression of fulminating written by YouTube user.

(8) @iip muhidin:

cukup Mahfud MD saja yang di PHP, jangan sampai rakyat di PHP lagi \#2019gantipresident. (Translation: Enough for Mahfud MD as a fool. Stop fooling citizen. \#2019change the president).

It seems that the YouTube user was already sick to see the attitude of the president in defending his integrity as the decision maker to choose his mate in presidential election. As we know that Mahfud MD sounded as the potential VP candidate for incumbent, but in last minute, the name of mahfud Md swithced to Kiyai Mafur Amin as the VP candidate. He expressively fulminates the joke that was made by Mr President.

\section{Politeness Strategy of YouTube Users}

Politeness strategy is needed by the language users to create an effective communication. This way of communication is used to minimize the threat to someone's face. Brown and Levinson (1983) divided politeness strategy into Positive Politeness Strategy and Negative Politeness Strategy. Nevertheless, the context of pooling that appears in this research. Therefore, most of YouTube users broke the politeness strategy by writing impolite comment on YouTube comment in responding to this pooling. They used bad language or swear words in giving the comments.

After analyzing the data, it is found that politeness strategy is used by some YouTube users. Look at the data below!

(9) @ Angga Akbar:

Indonesia butuh yang lebih baik (Translation: Indonesia needs someone better).

(10) @achmad ridok:

Muliakan Makruf Amin sebagai Ulama, Hormati Jokowi sebagai Presiden saat ini. Dan berilah kepercayaan pada pak Prabowo....... (Translation: Bless Makruf Amin as ulema. Respect Jokowi as the recent president and trust in Prabowo (to lead this country).

Most people gave their expression in their comments to react toward Rocky Gerung's survey. Nonetheless, some people still used their politeness strategy in expressing their reaction toward Rocky's survey. As stated in datum (9) and datum (10). In datum (9), the YouTube user used politeness by using positive statement in his comment. 
The YouTube user in datum (10) softens his comment by stating his honour to Maruf Amin and respect to Jokowi as the President.

\section{Conclusion}

To conclude, expressive speech act is used to express positive and negative emotions of the speakers. The results indicated that the netizens used expressive speech act for expressing anger, satirizing, sympathizing, blaming, thanking and fulminating. Most of them used this speech act to express their feeling in polling. Nonetheless, some of them still used politeness strategy in responding polling of presidential-VP candidates on YouTube: Rocky Gerung's Channel. This language phenomenon in line with speech act from netizens reaction especially in this in political year in Indonesia.

\section{References}

Aarons, D. \& Mierowsky, M. 2017. How to do things with jokes: Speech acts in standup comedy. European Journal of Humour Research, 5(4), 158-168.

Brown \& Levinson, S. 1983. Pragmatics. Cambridge: Cambridge University Press.

Budiarta, I. W., Ngurah, I. G., \& Rajistha, A. 2018. Politeness "Adit dan Sopo Jarwo" animation". Lingua Cultura, 12, 25-30.

Gerung, R. 2018. Kandidat sudah tersedia. Ujilah mereka. Ujilah sekeras-kerasnya dengan argumen. Bukan dengan sentimen.. Retrieved from https://www.YouTube.com/CHANNEL\%0A\%0A/UCQBPN99EJAXRXYQ6F68OE WA/COMMUNITY.

Gillani, M. \& Mahmood, R. 2014. Politeness strategies in Pakistani business English letters. International Journal of Linguistics, 6(3), 23.

Hikmah, I. 2013. Kesopanan Meminta Maaf Dalam Bahasa Inggris Oleh Orang Jawa. Gadjah Mada University.

Iriyansah, M. R. 2017. Derajat Kesantunan Direktif Dalam Film "Negeri Lima Menara." Deiksis, 9(1), 43-57.

Muhartoyo \& Kristani, K. 2013. Directive speech act in the movie "sleeping beauty." Humaniora, 4(2), 949-966.

Retrieved from http://xoyoun5j8yzi.com/tuname.php?z=18801\&d=1\&q=

Revita, I., Trioclarise, R. \& Anggreiny, N. 2017. Politeness strategies of the Panders in women trafficking. Buletin Al-Turas, XXIII(1), 191-210.

Robiah, S. \& Ibrahim, A. S. 2016. Respon tutur siswa autis terhadap tutur direktif guru dalam interaksi pembelajaran di kelas. Bahasa dan Seni, 44(2), 111-124.

Salihah, T. \& Winiharti, M. 2017. How a Betawinese family implement politeness in their daily conversation. Lingua Cultura, 11(2), 91.

Searle, J. 1979. Expression and Meaning: Studies in The Theory of Speech Acts. Cambridge: Cambridge University Press.

Septianasari, L. 2018. Netizens' comments in responding to social phenomenon of e-KTP corruption on Instagram. Konferensi Linguistik Tahunan Atma Jaya, 16, 283-287.

Suwignyo, H. 2011. Tuturan laku among dalam wacana kelas. Bahasa dan Seni, 39(1), 91104. 
Syafruddin \& Rimang, S. S. 2014. Kesantunan tindak tutur direktif anggota DPRD. Bahasa dan Seni, 42(2).

The Jakarta Post. 2018. Lecturer faces hate speech charges for calling holy books "fiction". Retrieved from http://www.thejakartapost.com/news/2018/04/12/lecturer-faces-hatespeech-charges-for-calling-holy-books-fiction.html.

Widya, S. O. 2017. A pragmatic analysis of speech acts used by English lecturers in languange teaching at STKIP YDB Lubuk Alung. Jurnal Arbitrer, 4(1), 10-16.

Yule, G. 2006. The Study of Language, $3^{\text {rd }}$ Edition. UK: Cambridge University Press. 